\title{
Türkiye'de Orak Hücreli Anemi Dağılımı, Patofizyolojisi ve Demir Toksisitesi
}

\author{
DERYA SÖYLEMEZ-GÖKYER, ZELİHA KAYAALTI
}

\section{ÖZET}

Hemoglobinopatiler dünyada en sık karşılaşılan tek gen hastalıklarındandır ve bunlardan Orak Hücreli Anemi (OHA) hastalığı ülkemizin de içinde bulunduğu Akdeniz kıyı şeridi bölgesinde görülme sıklığı yüksek olan otozomal resesif kalıtım geçişli ve birçok sistemi etkileyen bir kan hastalığıdır. OHA hastalarında hemoglobin $(\mathrm{Hb})$ proteininin yapısı sağlıklı bireylere göre farklılık göstermektedir. Bu bireylerde anormal bir $\mathrm{Hb}$ tipi olan mutant Hemoglobin S (HbS) proteini mevcuttur ve bu protein, oksijenli ortamda görevini normal olarak yapabilmektedir. Ancak, düşük oksijenli ortamda bu protein kırmızı kan hücrelerinin uzamış yarım ay ya da başka bir deyişle orak şeklini almasına, küçük damarlarda kümelenerek tıkanıklığa ve sonuçta dolaşımın akışkanlığının bozulmasına neden olmaktadır. Damar tıkanıklığına bağlı gelișen iskemi ise, organlarda hasara ve fonksiyon kaybına yol açmaktadır. Diğer taraftan sıklıkla uygulanan transfüzyonlar bu hastaların doku ve organlarında demir birikimine yol açmakta bu nedenle organlar etkilenmekte ve fonksiyonları bozulmaktadır. Biyolojik sistemlerde demir serbest radikallerin üretilmesinde önemli bir bileşendir. Son çalışmalar demir toksisitesinin serbest radikal oluşumuna etkisinin önemini göstermektedir. Sonuç olarak serbest demir oksidatif streste önemli bir rol oynar. Bu derlemede Türkiye'de Orak Hücre Anemi dağılımı, patofizyolojisi ve demir toksisitesi hakkında ayrıntılı bir şekilde bilgi verilecektir.

Anahtar kelimeler: Orak Hücreli Anemi, Hemoglobin, Hemoglobin S, Demir, Demir toksisitesi.
Derya Söylemez

Adli Bilimler Enstitüsü, Ankara Üniversitesi Tip Fakültesi Cebeci Yerleşkesi, 06590, Dikimevi, Ankara.

\section{Sorumlu Yazar:}

Zeliha Kayaaltı

Adli Bilimler Enstitüsü, Ankara Üniversitesi Tip Fakültesi Cebeci Yerleşkesi, 06590, Dikimevi, Ankara.

Tel: +90 312 3192734; Fax: +90 3123192077.

E-posta:kayaalti@ankara.edu.tr, zkayaalti@gmail.com

Submitted/Gönderilme: 02.12.2015

Revised/Düzeltme: 12.01 .2016

\section{Gíriş}

Dünyada ve ülkemizde görülme sıklığı ve taşıyıcıllğg yüksek olan hemoglobinopatiler en sık karşılaşılan tek gen bozukluklarıdır. Orak Hücreli Anemi (OHA) ya da diğer adıyla Orak Hücre Hastalığı $(\mathrm{OHH})$, otozomal resesif geçiş gösteren, dokulara oksijen taşıyan molekül olan $\mathrm{Hb}$ proteininin hasarlı sentezi sonucunda gelişen, anemi ile karakterize heterojen kalıtsal bir tür kan hastalığıdır. $\mathrm{Hb}$ molekülü bir çift alfa $(\alpha)$ ve beta $(\beta)$ globin zincirinden meydana gelmektedir $(1,2)$ (Şekil 1$)$.

$\beta$ globin zincirinin 6. aminoasidi olan glutamin aminoasidinin yerini valin aminoasidinin almasina neden olan nokta mutasyonu, normal HbA'nın yapısının bozularak mutant $\mathrm{HgS}$ sentezlenmesine neden olmaktadır $(3,4)$. OHA'da, hastalıklı gen otozomal resesif (eşeysel kromozomlara bakılmaksızın) olarak gelecek nesillere aktarılır. Orak hücre mutasyonu homozigot ya da heterozigot yapida olabilmektedir. Hasta olmayan bireyler HbAA, heterozigot (taşıyıcı) HbAS, homozigot hasta HbSS olarak adlandırılır. 
Heterozigot yapıdaki bireylerde ebeveynlerin sadece birinden $\beta$ globin zincirinin yapilmasindan sorumlu olan mutasyona uğramış geni alması durumunda kırmızı kan hücrelerinde $\mathrm{HbA}$ ile HbS bulunmaktadır. Bu yapıdaki $\mathrm{Hb}$ molekülüne sahip bireyler OHA taşıyıcısı olarak adlandırılmaktadır. Homozigot bireyler ise ebeveynlerin her ikisinden de $\beta$ globin zincirinin yapilmasindan sorumlu olan mutasyona uğramış geni alır. Bu durumda, bireyler $\mathrm{HbA}$ sentez edemez ve OHA hastalığı meydana gelmektedir. Genotip olarak OHA taşıyıcısı ebeveynlerden doğacak her bir çocuk için hastalıklı ya da normal doğma oranı \%25, taşıyıcı doğma oranı ise \%50'dir (Şekil 2) (5). Orak hücre geni homozigot (HbSS) olan bireylerde hastalığın klinik bulguları görülür. Orak hücre geni heterozigot (HbAS) olan orak hücre taşıyıcıları ise normal bir hayata sahiptirler ve genellikle bulgu vermezler.

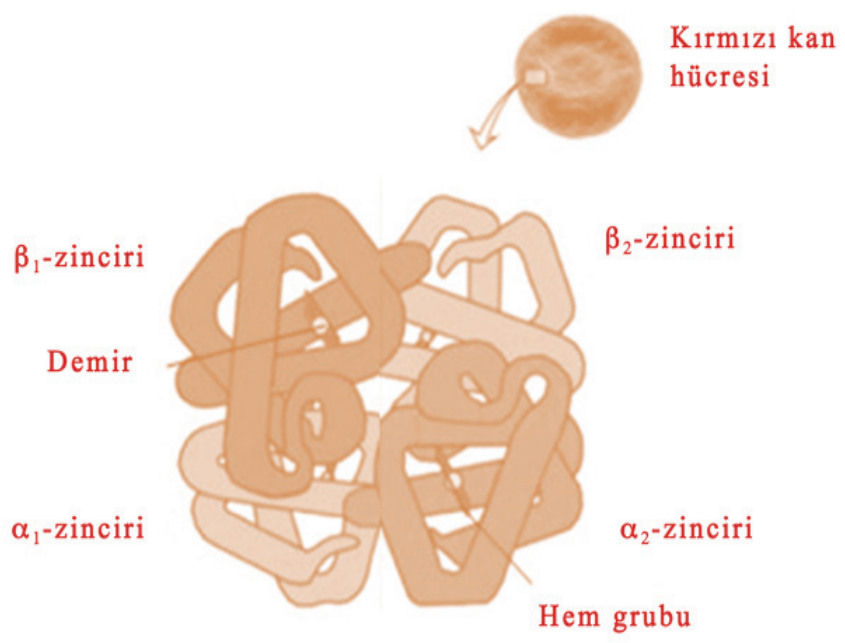

Şekil 1. Hemoglobinin şematik yapısı (1 numaralı referanstan modifiye edilmiştir).

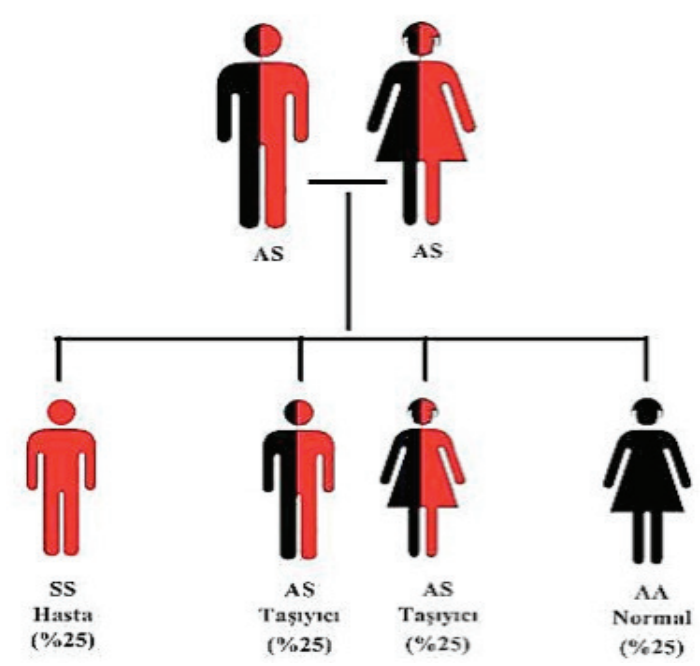

Şekil 2. OHA hastalığının genetik aktarımı (5 numaralı referanstan modifiye edilmiştir).
OHA hastalığı Afrika kıtası, Ortadoğu, Amerika, Ülkemizin de içinde bulunduğu Akdeniz kıyı bölgelerinde ve Hindistan'da geniş bir coğrafik dağılıma sahiptir (Şekil 3). OHA’nın dünyadaki dağılımını belirleyen iki önemli etken vardır. Bunlar malaryaya karşı sağladığı direnç ve sonradan gelen göçlerdir. Malaryanın endemik olduğu coğrafi bölgelerin birçoğunda yüksek frekanslarda görülmesinin en önemli nedeni OHA taşıyıcılarının eritrositlerinde malaryal parazitlerin yaşam döngüsünü tamamlayamadı̆̆ malarya normal eritrositlerin parçalanmasına sebep olurken, orak hücreli eritrositlere daha az zarar vermektedir. $\beta$ globin zincirinin yetersiz üretimine neden olan mutasyonun, homozigot ve heterozigot taşıyıcı bireyleri, malaryaya karşı genetik olarak kısmi koruduğu ve bu bireylerin belli bir doğal seleksiyon (natural selection) avantajına sahip olduğu düşünülmektedir. Bu genetik hastalığın iyi tarafı ise taşıyıcı bireylerin Plazmodium falciparum etkeni olduğu endemik malarya infeksiyonuna karşı gensel olarak hastalığın daha hafif derecede seyrettiği gözlenmiştir. Taşıyıcı bireylerde malarya hastalığını gösterme halinin ve ölüm oranının belirgin bir şekilde düşük olduğu saptanmıştır. Bir grup araştırmacı, OHA taşıyıcılığının sık görüldüğü Orta Afrika'daki ve tropikal bölgelerdeki olumsuz bir etkene karşı taşıyıcıların hayatta kalmasını kolaylaştırıcı bir etkisi olduğunu öne sürmüştür. Malarya ile OHA geninin coğrafik dağılımı arasındaki benzerlik; bu etkenin malarya olduğunu düşündürmüştür $(6,7)$.

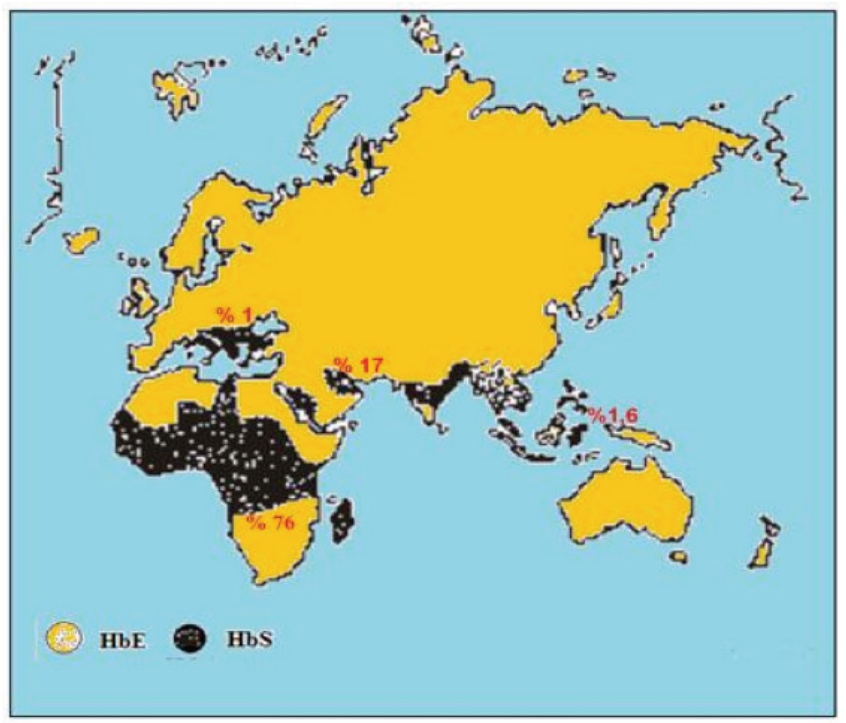

Şekil 3. Dünyada HbS molekülünün dağılımı (7 numaralı referanstan modifiye edilmiştir).

Ülkemizde OHA ile ilgili yapılan tarama çalışmaları, bu genetik hastalığın bazı bölgelerde yüksek oranlarda olduğunu göstermektedir. Özellikle Adana, Mersin ve Hatay gibi güney illerimizde OHA hastası ve taşıyıcısı sayısı yüksektir 
(8). Ülkemizdeki toplam OHA'li hasta sayısı yaklaşı 1200 civarında olup HbS sıklık oranı \% 0,03'tür (9). Ancak bu oran bölgeden bölgeye farklılık gösterebilmektedir. Sağlık Bakanlığ1 ve Ulusal Hemoglobinopati Konseyinin son verilerine göre taşıyıcı sıklığ $\% 13,6$, Antalya'da \%2,5, Diyarbakır'da \%0,5, Muğla'da \%0,5 sıklıktadır (Şekil 4) Çukurova bölgesi ülkemizde OHA’nın en sık yoğunlaştığı yöredir (10-13). Farklı yapılan tarama çalışmalarında ise frekans sıklı̆̆ Mersin'de \%15,3, Denizli'de ilköğretim öğrencileri arasında \%0,7, Samsun ilinde lise öğrencileri arasında \%0,05 saptanmıştır. Tarsus ilçesinde yapılan bir çalışmada HbSS \%0,43, taşıyıcılık \%8,61, HbS gen frekansı ise \%9,07 oranında tespit edilmiştir (14).

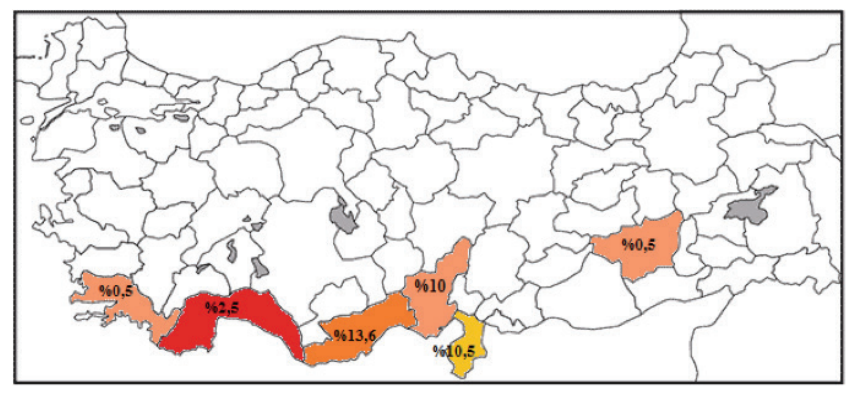

Şekil 4. OHA’nın Türkiyedeki dağılımı (14 numaralı referanstan modifiye edilmiştir).

\section{Patofizyolojisi}

OHA, 1910 yılında ilk kez Herrick tarafindan pulmoner semptomlar ile başvuran bir hastanın kan yaymasını incelemesi sırasında kırmızı kan hücrelerinin kendine özgü tuhaf bir görünümü olan "orak şeklinin” görülmesi ile tanımlanmıştır (Şekil 5). 1917 yılında Emmel bir OHA hastasının babasında orak hücrelerinin görülmesi neticesinde hastalığın kalıtsal olarak aktarıldığını açıklamıştır. Hahn ve Gillepsie hastalığın patolojik temelini ve hemoglobin molekülü ile ilgisini 1927 yılında tanımlamıştır.

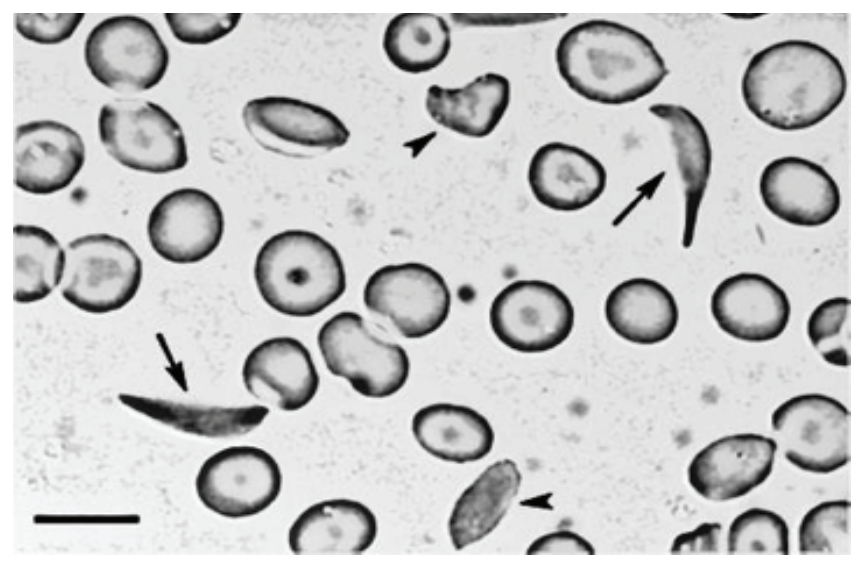

Şekil5. Orakhücrelerin kan yaymasınınışık mikroskobundaki görüntüsü (17 numaralı referanstan modifiye edilmiştir).
Hastalık patogenizini oluşturan mutant HbS, 11. kromozomun kısa kolunda yer alan, 146 aminoasitlik $\beta$ globin gen lokusunun amino (-NH2) ucunda 6. konumundaki tek mutasyon sonucu adenin bazının GAG (Guanin-AdeninGuanin) timin bazı GTG (Guanin-Timin-Guanin) ile yer değiştirmesiyle meydana gelmektedir (Şekil 6). Bu mutasyon sonucu DNA’nın baz sıralamasında veya içeriğinde meydana gelen değişime bağlı olarak; $\beta$ globin zincirinin amino terminalini oluşturan bu peptidin Valin-Histidin-LösinTreonin-Prolin-Glütamik asit-Glütamik asit-Lizin aminoasit dizisi yerine Valin-Histidin-Lösin-Treonin-Prolin-ValinGlütamik asit-Lizin gibi farklı amino asit dizisine ve tamamen farklı işleve sahip aktivitesi azalmış bir protein içerdiği tespit edilmiştir (15-17). Bu yapısal değişiklikten dolayı kırmızı kan hücrelerinin dış zarlarında bulunan hidrofilik aminoasit yerine hidrofobik aminoasidin geçmesi sonucu $\mathrm{Hb}$ molekülünün çözünürlük özelliğini etkilenmekte ve değiştirmektedir (16). Oksijenin azalması sonucunda HbS molekülleri HbA’ya göre daha az çözünür ve aşamalı olarak büyürler. Hb’nin fiziksel yapısındaki bozulma kırmızı kan hücrelerinin şekil değiştirmesine neden olur ve kırmızı kan hücreleri yeterince esnek olmayan, diğerlerine göre daha uzun olan yarımay şeklini ya da başka bir tanımla orak şeklini alırlar, bu durumda kırmızı kan hücreleri kılcal damarları tıkayarak dolaşım akışkanlığını azaltır ve kan akımını yavaşlatır (Şekil 7). Bu da özellikle bazı organların ya da dokuların yeterli oksijen almasını ve beslenmesini engeller, böylece tıkanan damarların olduğu her yerde sorunlar ortaya çıkar. Kanlanmanın bozulması dokularda hipoksi, ağrılı kriz, organ hasarı ve işlev kaybına, sonuçta akut ve kronik süreçte doku harabiyetine neden olmaktadır (16-18), diğer taraftan sıklıkla uygulanan kan transfüzyonlarına bağlı hasta bireylerin doku ve organlarında demir birikimine yol açmakta, bundan dolayı organlar etkilenmekte ve işlevleri bozulmaktadır. Orak şeklini alan hücrelerin bir kısmı geri dönüşümlü olup eski normal şeklini alabilmektedir. Şekli bozulmuş olan hücreler genellikle kısa ömürlü olup vücut tarafından dalak yardımıyla normal kan hücrelerine göre daha hızlı yıkıma uğrarlar. $\mathrm{Bu}$ da $\mathrm{OHA}$ hastalarının kırmızı kan hücrelerinin normalden kısa ömürlü olmasının nedenidir ve anemi krizinin şiddetiyle doğrudan ilişkilidir (19). Şekli bozulmuş kırmızı kan hücrelerinin erken yıkımından ötürü geriye az miktarda normal kırmızı hücre kalır bu da kansızlığa yol açmaktadır. Kansızlık neticesinde kısa sürede yorulma, iştahsızlık, yorgunluk ve kulakta çınlama meydana gelir. Kırmızı kan hücrelerinin erken ve hızlı yıkımından dolayı kırmızı hücre içerisinde bulunmakta olan bilirubin bir dizi kimyasal reaksiyonla ortaya çıkar. Kansızlık ya da safra yollarının tıkanmasıyla kanda bilirübin yükselir. Bilirübin deride ve gözlerde sarı renk oluşturmasıyla 
bilinmektedir. Serum bilirubin seviyesinin $100 \mathrm{mg} / \mathrm{dl}$ seviyesini aşması ile karakterize, genelde ölümle seyreden ilerleyici karaciğer büyümesine (hepatomegali) neden olur. Bilirübin OHA hastalarında açlığa, yorgunluğa ve enfeksiyonlara karşı artmış duyarlılık gösterirler. Enfeksiyonlarda kırmızı hücre yıkımı hızlı bir biçimde olmakla birlikte cilt renginin solgunlaşması, deride ve gözde sarılık, koyu renkte idrar yapılması, kalp çarpıntısı, baş dönmesi, bayılma ve nefes almada zorluk gibi belirtilerle de karşılaşılabilmektedir. Böyle bir duruma anemik (kansızlık) krizi denir ve bu tür durumlarda kırmızı kan hücrelerinin oraklaşması artar. Aynı zamanda vücudun oksijene ihtiyacı olduğu durumlarda (ağır uğraşlarda, ağır sporlarda, enfeksiyonlarda, aşırı yorgunlukta, uykusuzlukta, dehidratasyonda, vücudun fazla miktarda su kaybettiğinde, aşırı soğuklarda) orak şeklini kırmızı kan hücreleri birbirine geçerek kenetlenirler ve kümeleşerek küçük kılcal damarların tıkanmasına neden olur ve organlara yeteri miktarda kan ulaşamaz. Buna damar tıkanması krizi denir. Vücudun hangi damarları tıkanmışsa şikayetler ona bağlı olarak gelişiri (20-24).

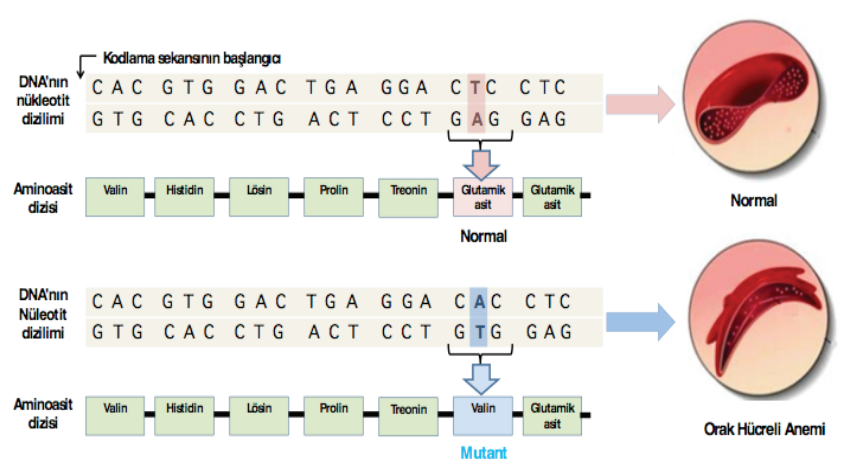

Şekil 6. $\beta$ geni normal ve mutant $\mathrm{Hb}$ gen dizisi (16 numaralı referanstan modifiye edilmiştir).

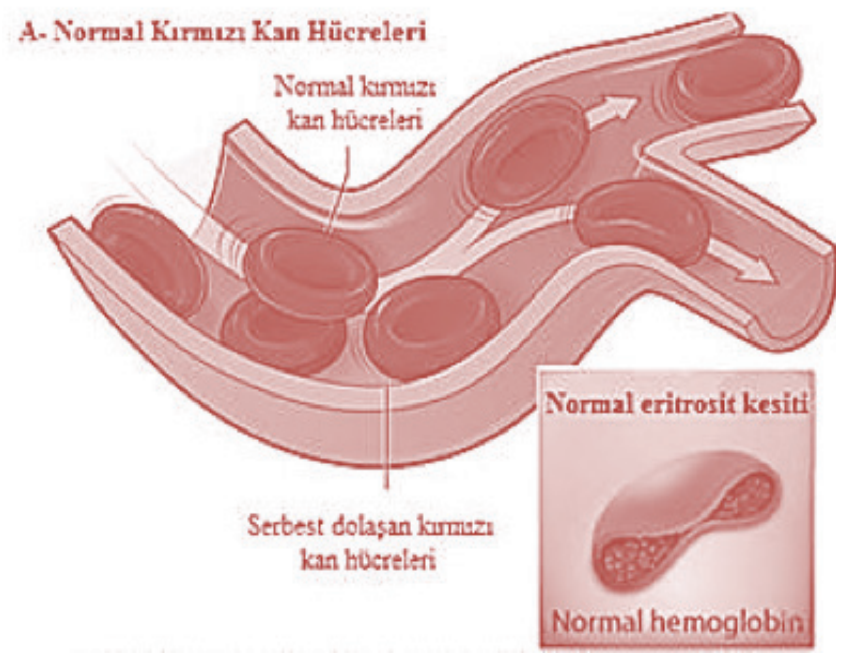

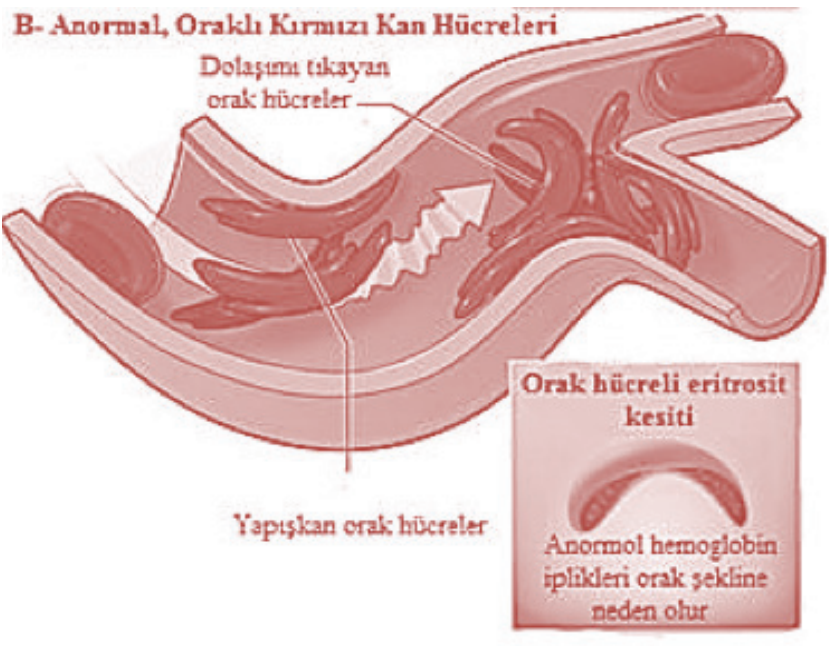

Şekil 7. Normal (A) ve orak (B) eritrositlerin damarlardaki dolaşımı (24 numaralı referanstan modifiye edilmiştir).

\section{Demir Toksisitesi}

Demir canlılar için esansiyel bir element olup vücutta birçok biyokimyasal fonksiyona sahiptir. En önemli fonksiyonlarından biri elektron alıp verme özelliğinden dolayı hemoglobin aracılığı ile oksijen taşımaktır. Bunun yanında, enerji yapımı, DNA, RNA, protein sentezinde ve pek çok yaşamsal önemi olan enzimin yapı ve fonksiyonunda görev almaktadır. Demir ferröz $\left(\mathrm{Fe}^{+2}\right)$ ve ferrik $\left(\mathrm{Fe}^{+3}\right)$ durumlar arasında kolaylıkla birbirine dönüşebilme özelliğinden dolayı oksijenasyon, hidroksilasyon ve buna benzer birçok esansiyel metabolik olayda görev almaktadır. $\mathrm{Bu}$ nedenle, demir insan yaşamı için vazgeçilmez bir elementtir ve demir metabolizmasındaki değişiklikler insan sağlığını önemli şekilde etkilemektedir (25).

Demir, vücutta sıkı bir şekilde kontrol altında tutulmaktadır. Normal bir beslenme ile ortalama günlük 10$20 \mathrm{mg}$ demir alınmakta ve bunların sadece 1-2 mg kadarı barsaktan emilmekte, bunun dışında organizma mevcut demirini tekrar kullanarak demir ihtiyacını karşılamaktadır. Demir $\mathrm{Fe}^{+2}$ iyonu şeklinde aktif transport yoluyla emilmekte, kanda demir taşıyıcı protein olan transferine bağlı olarak taşınmakta, böylece vücutta transferin reseptörüne sahip olan herhangi bir doku tarafindan kullanıma hazır yapıda bulunmaktadır. Transferinin normal bireylerde demir bağlama kapasitesi \%20-35 arasında bulunmaktadır. Vücut demir depoları boşaldığında veya eritropoez arttığında demir emilimi artmaktadır. Demir ilk olarak kemik iliği ve retiküloendotelyal sistem (karaciğer ve dalak) tarafından depolanır. Retiküloendotelyal sistemin demir depolama kapasitesi aşılınca transferinin demir plazma bağlama 
kapasitesi doygunluğa ulaşmakta ve plazmada transferine bağlı olmayan demir (serbest demir, non transferin bound iron, NTBI) oranında belirgin bir artış olmaktadır. NTBI albumin, sitrat, aminoasit, şekerler ve diğer küçük moleküllere bağlanıp zayıf kompleksler oluşturarak transferine bağlı olan demirden farklı davranışlar sergiler. Parankimal hücreler içinde, sitoplazmik iron responsive protein (IRP) tarafından kontrol edilen labil plazma demir (LPI) havuzu artınca, bir korunma mekanizması olarak, transferrin demirinin hücre içine girişi engellenir. Ancak NTBI’nın doğrudan hücrelere girişi, transferrin demirinden çok daha hızlı olarak devam eder. Karaciğer, endokrin organlar, kalp, böbrek, iskelet sistemi ve deri gibi organlarda NTBI birikimi olur. Bu durum LPI havuzunun kontrol edilemez bir şekilde genişlemesine yol açar. Yüksek oranda bulunan ve hücre içi demir bağlama kapasitesini aşan LPI hücreler için en toksik formdur. Bu da hücre içinde LPI’in oksijen ilişkili doku hasarlanmasına ve bunu takiben organ fonksiyon bozukluğuna neden olabilecek reaktif oksijen radikallerine ve demir toksisitesine yol açar (25).

Serbest radikaller, radikal olmayan bir atom veya molekülden bir elektron çıkarılması ya da eklenmesi sonucu elektron çiftinin dengesini kaybetmesiyle meydana gelen, dış atomik orbitallerinde bir veya birden fazla ortaklaşmamış elektron içeren, organik ve inorganik moleküller ile reaksiyona girebilme özelliği bulunan, yüksek enerjili, kararsız, düşük molekül ağırlıklı ve kısa ömürlü kimyasal türlerdir. Serbest radikallerin özelliği, dengesiz ve ortaklanmamış bu elektronu çiftlemek ve daha kararlı bir hale gelmek için diğer moleküller ile reaksiyona girme eğiliminde olmalarıdır. Biyolojik sistemlerde serbest radikaller ve reaktif oksijen türevleri en fazla elektron transferi sonucu meydana gelmektedir. $\mathrm{Bu}$ bileşikler hücresel koşullarda vücuttaki metabolik dengenin doğal ürünü olarak normal hücre metabolizması sonucunda oksijen içeren çeşitli biyokimyasal olaylar nedeniyle reaktif oksijen radikallerini devamlı üretirler. Başlıca önemli reaktif oksijen türleri; tekli oksijen $\left({ }^{1} \mathrm{O}_{2}\right)$, süperoksit anyonu

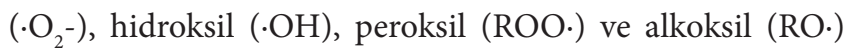
radikalleridir. Biyolojik sistemlerde serbest radikaller, reaktif oksijen türleri ve antioksidan savunma sistemleri arasında önemli bir denge söz konusudur. Serbest radikaller, reaktif oksijen türleri ve antioksidan savunma sistemi arasındaki bu dengenin serbest radikaller yönüne kayması durumunda oksidatif stres meydana gelir. Serbest radikaller etkilerini protein, lipit, karbonhidrat ve DNA oksitlenmesi oluşturarak; hücre zarında, hücre organellerinde ve DNA'da farklılıklar meydana getirirler. Bu serbest radikaller ve reaktif oksijen türleri antioksidan sistem tarafından etkisiz hale getirilirler.

Biyolojik sistemlerde yer alan serbest radikallerin oluşumu ve metabolizmasında $\mathrm{Hb}$ yapısında bulunan demir önemli bir bileşendir (25-27). Demir; katalaz, akonitaz, ribonukleotid redüktaz, peroksidaz, sitokrom oksidaz gibi enzimlerle redoks kimyasını kullanarak vücuttaki hayati fonksiyonlarda görev alan, $\mathrm{Hb}$ ve diğer Fe içeren proteinlerin yapısına giren bir elementtir. NTBI hemen hemen tüm dokularda birikmekte ve çeşitli reaksiyonlara girerek oksidan maddeler oluşturmaktadır. Bunlardan en önemlisi hidroksil radikalinin üretildiği Fenton reaksiyonu'dur.

Orak Hb’nin temelinde yer alan negatif yüklü glutamik asit yerine, nötr bir aminoasit olan valinin geçmesiyle $\mathrm{HbS}$ tetramerinin yüzeyi daha hidrofobik hale gelir. Oksijenini bırakan, deoksi HbS molekülünün çözünürlüğü ve elektroforetik hareketliliği normal Hb’den farklı olduğu gibi yapısı da kararsızdır.

Klinik tedavide sık kan transfüzyonu sonucu aşırı demir yüküne maruz kalan hastalarda, serbest radikaller artması durumunda dokularda hasar meydana getirmektedir. OHA'l hastalarda kan transfüzyonları ve anemi kriziyle birlikte dalak orak şeklindeki kırmızı kan hücrelerini ortadan kaldırmaya böylelikle yeni kırmızı hücre üretimi tetiklenmeye başlar bunun sonucunda intestinal demir emilimi tetiklenir ve organlarda demir birikimi gözlemlenebilir. Oksidatif hasar durumunda ve demir gibi metal iyonlarının varlığında serbest radikallerin üretimi artmaktadır.

OHA hastalığında oksidatif hasarın üç nedeni vardır:

1. Kırmızı kan hücrelerindeki HbS oksitlenmesine (oksidasyonuna) bağlı gelişen yağların bozulması (peroksidasyon) ve serbest radikal oluşumu,

2. Damar tıkanıklı̆̆ı sonrası gelişen yeniden kanlanma (reperfüzyon) hasarından kaynaklanan serbest radikaller,

3. Kırmızı kan hücreleri içinde ve dolaşımda azalmış antioksidan yoğunluğu (28-30).

Hb’nin oksijene bağlanması ve bırakması sırasında $\mathrm{Hb}$ yapısındaki iki değerlikli demirin üç değerlikli demire yükseltgenmesi ile methemoglobin (MetHb) meydana gelir. Hb’nin normal oksijenasyonu demirden bir elektronun transferine neden olur; deoksijenasyonla elektron tekrar demire transfer olur, oksijen salınır. Eğer elektron dönüşü olmazsa metHb oluşur. Hb'ye oksijen bağlanması sırasında güçlü bir oksidan olan süperoksit anyonu oluşur. Son derece toksik olan süperoksit anyonu, süperoksit dismutaz (SOD) etkisiyle hidrojen perokside dönüşür. Hidrojen 
peroksit $\left(\mathrm{H}_{2} \mathrm{O}_{2}\right)$ de toksiktir; katalaz ve glutatyon peroksidaz etkisiyle etkisiz hale getirilir. Oksijen bağlama yeteneği olmayan Hb’nin oksidasyon ürünü olan metHb birikimi ile oksijen transportu bozulur. Normal bireylerde metHb eser miktardadır ve hızlıca Hb’ye indirgenir (31).

OHA'lı bireylerde serbest, sağlam olmayan $\mathrm{Hb}$ molekülleri, biyolojik sistemlerde süperoksit ve hidroksil radikali üretiminin önemli bir kaynağıdır. Bu radikaller oksidatif hasar olaylarını başlatmaktadırlar. Hb’nin yapısında yer alan $\mathrm{Fe}^{+2}$ değerlikli demirin ilaçlar, serbest radikaller veya $\mathrm{H}_{2} \mathrm{O}_{2}$ gibi endojen ürünlerin etkisi ile oksitlenerek $\mathrm{Fe}^{+3}$ dönüşmesi durumunda önce Hb’nin üç boyutlu yapısını bozarak, oksijen taşıyamaması süreci olarak bilinen metHb oluşur ve sonra geri dönüşümlü ve geri dönüşümsüz hemikrom olarak çökerler ve hücre zarının çeşitli bileşikleri ile reaksiyona girerler. Hem ve globini parçalarlar. Hemin yıkımı ile açığa çıkan serbest demir Fenton reaksiyonu yolu ile çok güçlü şekilde serbest radikal oluşumuna yol açmaktadır. Oksijen radikalleri oluşumu ve salınımı HbS'de HbA’ya göre daha hızlıdır $(32,33)$.

Aşırı demir birikimi Fenton ve Haber-Weiss reaksiyonları oluşumuna neden olur. $\mathrm{Bu}$ reaksiyonda normal hücresel reaksiyonlar sonucu oluşan hidrojen peroksit demir ile reaksiyona girer ve $\mathrm{Fe}^{+2}$ değerlikli demir $\mathrm{Fe}^{+3}$ değerlikli hale gelir, beraberinde serbest hidroksil radikalini $(\mathrm{OH} \cdot)$ oluşturur. Sonuç olarak meydana gelen bu ürünler demirin indirgeyici özelliğinden dolayı proteinlerin oksidasyonuna, hücre zarı, lizozom ve mitokondri gibi diğer organellerdeki lipidlerinin peroksidasyonuna ve nükleik asitlerin modifikasyonuna neden olmakta ve ilerleyici parankimal hücre hasarı oluşmasına yol açmaktadır. Hücrelerde yüksek miktarda demir bulunması, transferrin, ferritin ve diğer demir bağlayıcı proteinlerin bozukluklarına neden olmaktadır. Tüm bu reaksiyonlar ve hücre hasarı demirin aşırı birikimi OHA’lı bireylerde daha fazla görülmekte ve bu da aşırı demir birikiminde görülen doku ve buna bağlı organ hasar ve yetmezliklerinin başlıca nedenini oluşturmaktadır. Organlar demir toksisitesine çok hassastır. Bu nedenle demir birikimi, kalp yetmezliği, siroz ve endokrin anomalilerine yol açabilmektedir (Şekil 8) $(34,35)$.

$$
\begin{array}{ll}
\mathrm{Fe}^{3+}+\mathrm{O}_{2}^{--} \longrightarrow \mathrm{Fe}^{2+}+\mathrm{O}_{2} \\
\mathrm{Fe}^{2+}+\mathrm{H}_{2} \mathrm{O}_{2} \longrightarrow \mathrm{Fe}^{3+}+\cdot \mathrm{OH}+{ }^{\circ} \mathrm{OH} & \text { Fenton reaksiyonu } \\
\mathrm{O}_{2}^{-}+\mathrm{H}_{2} \mathrm{O}_{2} \longrightarrow \mathrm{O}_{2}+{ }^{-} \mathrm{OH}+{ }^{\circ} \mathrm{OH} & \text { Haber-Weiss Reaksiyonu }
\end{array}
$$

Şekil 8. Fenton ve Haber-Weiss reaksiyonları.
OHA'lı bireylerde damar tıkanması sonrası gelişen yeniden kanlanma hasarı, toksinlerine karşı vücudun göstermiş olduğu reaksiyon, oksidatif stresin arttığı biyolojik sürecin göstergesi ve artan oksidatif stresin sürekli endotelin etkilenmesine neden olduğu tespit edilmiştir (Şekil 9).

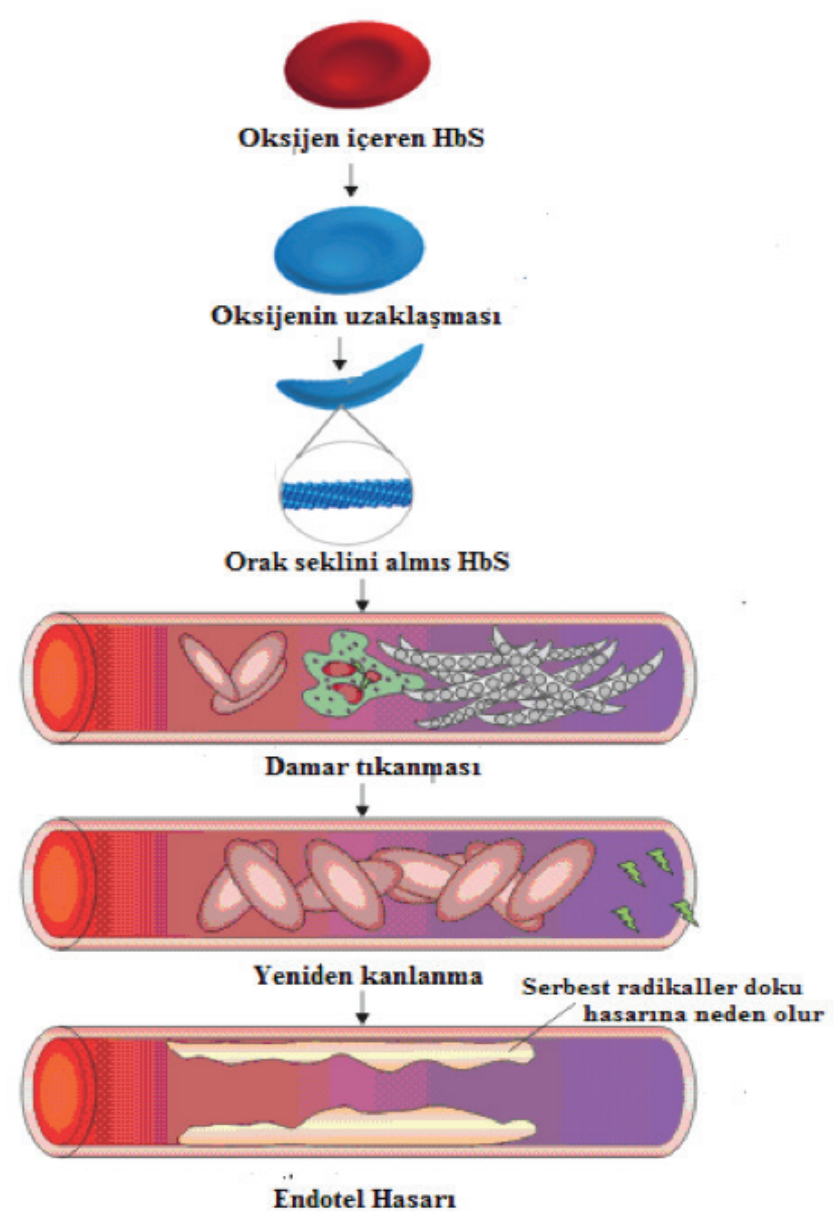

Şekil 9. Orak hücre anemide hasar oluşumu (15 numaralı referanstan modifiye edilmiştir).

Yapılan çalışmalarda, OHA’lı bireylerde oksijen varlığında HbS'nin HbA'ya göre artmış miktarda radikal zincir reaksiyonu hızına sahip olduğu ve OHA bireylerinin kırmızı kan hücrelerinde yüksek miktarda süperoksit ve hidroksil radikalleri bulunduğu tespit edilmiştir. HbS’nin kırmızı hücre zarına tutunduğu ve bir Fenton reaktifine benzer biçimde hareket ederek süperoksit ve hidroksil radikali gibi oksidan ajanların üretimini arttırdığını tespit etmişlerdir (36, 37). Bunun yanı sıra HbS'nin yüksek oranda radikal zincir reaksiyonu ve denatürasyonu nedeniyle hücre zarında demir bileşenlerinin birikimini meydana getirdiği belirlenmiştir (38).

OHA'li hastalarda etkin olmayan kan yapımıla daha az 
karşılaşılması ile tekrarlayan transfüzyonlar olmadan demir birikimi meydana gelmez. Ancak, vücutta biriken demirin atılımını sağlayan herhangi fizyolojik bir mekanizma bulunmaması nedeni ile tekrarlayan transfüzyonlar sonucunda vücut demir yükü artmakta ve bu durumda hastalarda karaciğer, kalp ve endokrin organlarda demir birikimi olmaktadır. Demir vücuttan başlıca bağırsak hücreleri, safra, dışkı, tırnaklar, saç ve idrar yoluyla atılmaktadır $(39,40)$.

\section{SONUÇ}

Sağlık alanında, kan hastalıklarının tedavisinde ve yeni yöntemlerin araştırılmasının yanında sağlıklı bir yaşam sürdürmek ve hastalıkları önlemek açısından önemli araştırmalar yapılmaktadır. Günümüzde orak hücreli anemililer, demir toksisitesi ve serbest radikallerle olan ilişskilerine yönelik araştırmalar yapılmaktadır. Orak hücreli

\section{Distribution of Sickle Cell Anemia in Turkey, Pathophysiology and Iron Toxicity}

\begin{abstract}
Hemoglobinopathies is one of the most extensive single gene disorders in the world and one of the most important type of these diseases, sickle cell disease (SCD) is an autosomal recessive inherited disorder of the red blood cells and affects many systems, is seen frequently both for the our country and for Mediterranean coastline region. The structure of the hemoglobin protein in patients with SCD is different when compared to healthy individuals. Patients with SCD have abnormal types of $\mathrm{Hb}$, called mutant Hemoglobin $\mathrm{S}(\mathrm{HbS})$ protein and this protein is able to work as normal in an oxygenated environment. However, in an oxygen poor environment this protein may cause the shape change
\end{abstract}

anemililerde hemoglobinde meydana gelen tek nokta mutasyonu farklı bir yapıda hemoglobin oluşturmaktadır. Kan transfüzyonu alımı, anemi varlığı veya hızlanmış eritropoez varlığı demir emilimini artırmaktadır. Demirin redoks reaksiyonlarını katalize edebilme özelliği demir toksisitesinin başlıca nedenidir. Normal hücresel reaksiyonlar sonucu oluşan reaktif oksijen ara ürünleri olan süperoksit ve hidrojen peroksit, organizmanın bunları uzaklaştırma kapasitesinin üzerine çıktı̆̆ında oksidatif stres gelişmektedir. Oksijen ara ürünleri demire bağımlı Fenton reaksiyonu serbest radikal oluşumuna neden olarak, dokularda hücresel hasar meydana getirebilmektedirler. Serbest radikaller, hücre yaşamı üzerine olan etkilerinden dolayı, büyüme ve gelişme üzerinde oldukça etkilidirler. Serbest radikaller, demir toksisitesi ve orak hücre anemi hastalı̆̆ı arasındaki ilişki araştırılıp hasta bireylerin yaşamını kolaylaştırmak için daha uygun ve etkili tedavi yöntemleri geliştirilebilir.

in red blood cells. In other words they take the form of elongated half moon or sickle shaped. The misshapen red cells can jam the tiny vessels as a result, imparing circulation and slows or stops the flow of blood. Vaso occlusive events result in tissue ischemia leading to organ damage and loss of organ function. On the other hand, repeated blood transfusions lead to iron overload in the tissues and organs of these patients. Therefore organs affected and functions are disrupted. Iron is a major component in the production and metabolism of free radicals in biological systems. Last studies indicate a significance of free radical mediated iron toxicity. In conclusion, free iron plays a crucial role in oxidative stress. In this review, detailed information about the pathophysiology, iron toxicity and distribution of sickle cell anemia will be given in Turkish population.

Keywords: Sickle cell disease, Hemoglobin, Hemoglobin S, Iron; Iron toxicity.

\section{KAYNAKLAR}

1. Eaton WA, Henry ER, Hofrichter J, Bettati S, Viappiani C, Mozzarelli A. Evolution of allosteric models for hemoglobin. IUBMB Life 2007;59:586-99.

2. Voskou S, Aslan M, Fanis P, Phylactides M, Kleanthous M. Oxidative stress in $\beta$-thalassaemia and sickle cell disease. Redox Biol 2015;6:226-39.

3. Hockham C, Piel FB, GuptaS, Penman BS. Understanding the contrasting spatial haplotype patterns of malariaprotective $\beta$-globin polymorphisms. Infect Genet Evol 2015; 36:174-83.

4. Birgens H, Ljung R. The Thalassaemia Syndromes. Scand J Clin Lab Invest 2007; 67:11-26.
5. Tüzmen Ş, Scheter AN. Genetic Diseases of Hemoglobin: Diagnostic methods for elucidating Sickle Cell Mutations. Blood Reviews 2001;15:19-25.

6. Rees DC, Williams TN, Gladwin MT. Sickle-cell disease. Lancet 2010;376:2018-31.

7. Weatherall DJ, Clegg JB. Inherited haemoglobin disorders: an increasing global health problem. Bull World Health Organ 2001;79:704-12.

8. Yüregir GT, Donma O, Dikmen N, Isbir T., Cinar M. Population studies of Haemoglobin $\mathrm{S}$ and other variants in Çukurova, The Southern part of Turkey. Acta Haematol Jap 1987; 50:757- 65. 
9. Arcasoy A. Dünyada ve Türkiyede talasemi ve hemoglobinopatiler. Hemoglobinopati ve Talasemi Önlem-Tanı-Tedavi. Ulusal Hemoglobinopati KonseyiSağlık Bakanlığı 2003 2.Baskı; Antalya: 11-19.

10. Gümrük F, Altay Ç. Orak hücre anemisi. Katkı 1995;16:327-45.

11. Arpacı A, Aksoy K, Dikmen N. Çukurova'da orak hücre anemisi ve talasemi taraması. XXII. Ulusal Hematoloji Kongresi, İstanbul 1991: 115.

12. Eraslan S. Beta Talaseminin Moleküler Tanısı. Düzen Genetik Hastalıklar Tanı Merkezi, Ankara-Türkiye, 2005.

13. Kılınç Y, Akmanlar N, Kümi M, Köker I. The incidences of hemoglobinopathies and thalassemias in cord blood of newborns from Çukurova Province. Med Bull İstanbul Medical Faculty 1992; 25: 9- 14.

14. Canatan, D., Aydınok, Y. Talasemive Hemoglobinopatiler. Tanı ve Tedavi; Retma Matbaacılı Antalya, 2007; 11-19.

15. Serjeant GR. The emerging understanding of sickle cell disease. Br J Haematol 2001; 112:3-18.

16. Yüksel, R. Homozigot Hbss Erişkin Orak Hücre Anemili Hastalarda Serum pedf Düzeyleri ile Hscrp arasındaki ilişkinin incelenmesi. Uzmanlık tezi, Tibbi Biyokimya Anabilim Dalı, Hatay, 2014; 3 s.

17. Frenette PS, Atweh GF. Sickle cell disease: old discoveries, new concepts, and future promise. J Clin Invest 2007;117:850-8.

18. Noguchi CT, Schechter AN. The intracellular polymerization of sickle hemoglobin and its relevance to sickle cell disease. Blood 1983;58:1057-68.

19. Porter JB. Pathophysiology of transfusional iron overload: contrasting patterns in thalassemia major and sickle cell disease. Hemoglobin 2009;33:37-45.

20. Ebert EC, Nagar M, Hagspiel KD. Gastrointestinal and hepatic complications of sickle cell disease. Clin Gastroenterol Hepatol 2010;8:483-9.

21. Charache S, Terrin ML, Moore RD, Dover GJ, Barton FB, Eckert SV, McMahon RP, Bonds DR. Effect of hydroxyurea on the frequency of painful crises in sickle cell anemia. Investigators of the Multicenter Study of Hydroxyurea in Sickle Cell Anemia. N Engl J Med 1995;332:1317-22.

22. Elsharawy MA, Moghazy KM, Shawarby MA. Atherosclerosis in sickle cell disease - a review. Int J Angiol 2009;18:62-6.

23. Samuels-Reid JH. Common problems in sickle cell disease. Am Fam Physician 1994; 49:1477-80.
24. Öztaş YE. Orak hücreli anemide plazma ve eritrosit ortamındaki değişimlerin biyokimyasal parametrelerle incelenmesi. H.Ü. Sağlık Bilimleri Enstitüsü, Ankara, 2010; 10 s.

25. Anderson GJ. Mechanisms of iron loading and toxicity. Am J Hematol 2007;82:1128-31.

26. Mercan U. Toksikolojide Serbest Radikallerin Önemi. Yüzüncü Yıl Üniversitesi Vet Fak Derg 2004;15:91-6.

27. Halliwell B. Free radicals and antioxidants: updating a personal view. Nutr Rev 1994;52:253-65.

28. Asakura T, Minakata K, Adachi K, Russell MO, Schwartz E. Denatured hemoglobin in sickle erythrocytes. J Clin Invest 1977;59:633-40.

29. Rund, D, Rachmilewitz, E. New treatment of $\beta$-thalassemia. Critical Reviews in Oncol Hematol 2000;33:105-18.

30. Liu SC, S. Zhai, Palek J. Detection of hemin release during hemoglobin S denaturation. Blood 1988;71:1755-8.

31. KILINÇ Y. Anormal Hemoglobinler. Türk Çocuk Hematoloji Derg 2008; 6-18.

32. Aslan M, Thornley-Brown D, Freeman BA. Reactive species in sickle cell disease. Ann N Y Acad Sci 2000; 899:375-91.

33. Comporti M, Signorini C, Buonocore G, Ciccoli L. Iron Release, Oxidative Stres and Erythrocyte Ageing. Free Rad Bio Med 2002; 32:568-76.

34. Hori A, Mizoue T, Kasai H, et al. Body iron store as a predictor of oxidative DNA damage in healthy men and women. Cancer Sci 2010;101:517-22

35. Harrison SA, Bacon BR. Hereditary hemochromatosis: update for 2003. J Hepatol 2003; 38:14-23.

36. Hebbel RP, Morgan WT, Eaton JW, Hedlund BE. Accelerated autoxidation and heme loss due to instability of sickle hemoglobin. Proc Natl Acad Sci USA 1988;85:237-41.

37. Repka T, Hebbel RP. Hydroxyl radical formation by sickle erythrocyte membranes: role of pathologic iron deposits and cytoplasmic reducing agents. Blood 1991;78:2753-8.

38. Rother RP, Bell L, Hillmen P, Gladwin MT. The clinical sequelae of intravascular hemolysis and extracellular plasma hemoglobin: a novel mechanism of human disease. JAMA 2005; 293:1653-62.

39. Şamaz İ. Orak Hücre Anemisinde Transfüzyon Seçenekleri Ve Şelasyon. 5. Uluslararası Talasemi Yazokulu 2008;161-6.

40. Beutler E. Hemochromatosis: genetics and pathophysiology. Ann Rev Med 2006; 57:331-47. 